\title{
Teacher-Related Factors in Educational Crises: The Way Forward in Nigeria's Case
}

\author{
Ige Akindele, $\mathrm{M}^{1, *}$ \\ ${ }^{1}$ Ministry of Education, Akure, Ondo State, Nigeria \\ *Correspondence: E-mail: dele_divine@yahoo.co.uk
}

Received: November 19, 2011 Accepted: November 20, 2012 Published: December 25, 2012

doi:10.5296/ije.v4i4.2953ＵRL: http://dx.doi.org/10.5296/ije.v4i4.2953

\begin{abstract}
That educational system in Nigeria is plagued by crises cannot be doubted. The system has often been criticized for its glaring failure, particularly in ensuring the turnaround of the country which has been the basis for the commitment of financial, human, and material resources to it by government and private sector in the society. It is pertinent to note that many among the educational crises centre round teachers. Many are even arguing that removing teacher related factors from educational crises in Nigeria, the crises are half-solved. In this paper, issues of inadequacy of teachers; low quality teachers; and other aspects of educational crises that relate to teachers were examined. In view of the negative effects of the crises on the educational system, tackling them and moving education forward in the country are imperative in this $21^{\text {st }}$ century. Achieving this feat however calls for the recruitment of additional qualified teachers, motivation, training, re-training, proper monitoring, as well as effective discipline of teachers, among others, as recommended in the latter part of the paper.
\end{abstract}

Keywords: Teacher; Factor; Teacher-Factor; Education; Crises; Educational Crises; Way forward; Nigeria; Case 


\section{Introduction}

Different crises with different magnitudes, are plaguing educational system in Nigeria. Notable among these crises are: policies instability, poor implementation of policies, inadequate funding, limited access to school, inadequate infrastructural facilities, improper planning and implementation, corruption, rising population, unemployment, wastage (repetition and dropout) just to mention few (Adeyemi \& Ige,2002; Ajayi \& Shofoyeke, 2003; Okebukola, 2002; Saint, Hartnett \& Strassner, 2003; Obanya, 2004; Ige, 2011; Ibeh, 2009). Of all the crises however, those that centre round teachers are significant and worthy of attention because of their invaluable roles in the education process. According to Ibukun (2009), teachers are at the central stage in the translation of carefully prepared education plans into reality at the operational and grassroots levels. It is upon their number, quality, devotion, and commitment to duty that depend the success and progress of any educational system. In Nigeria, educational crises are historic. They take their roots from the period when the Christian Missionaries were in the saddle. Reports (Adesina, 1977; Fafunwa, 1974) indicate that the Missionaries introduced western education amid Christianity and Islam which were the dominant religions then. Most of the people then were reluctant to imbibe western education because of the fear of losing their doctrines through it. The lackadaisical attitude which was shown to western education at the onset, contributed immensely to the limited enrolment that characterized the earliest schools (Adesina, 1977). The colonial governments did not initially show interest in the administration and financing of western education because they regarded it to be outside their priority. Consequent upon this were the issues of inadequate funds, teachers, infrastructural facilities, as well as organizational crises in schools (Adesina, 1977). The growth in Nigeria's educational system occasioned by increase in the number of schools/educational institutions as well as their enrolment (Ukeje, 1991; Central Bank of Nigeria, 2010), has led to complexities in the administration of the system and emergence of additional crises in the system.

\section{Education Concept: Scope and Purposes in Nigeria}

Education is defined as: any act or experience that has formative effect on the mind, character, and physical ability of an individual (Chukwuemeka, 2011); the process of providing information to an inexperienced person so as to help him/her develop physically, mentally, socially, emotionally, spiritually, politically, and economically (Offorma, 2009). Notwithstanding the different definitions of education in literature, it is certain that education can equip individual with knowledge, skills, traits, and experiences that will enable him/her to live comfortably and contribute to the development of his/her society. It can also facilitate functional co-existence, enhance individual's usefulness to self and society, develop and build up human mind, skills, and values through judicious combination of many variables involving the nature of the pupil/student, content and manner of instruction, instructional process, and the state of mind of both the teacher and learner.

Education can be informal, non-formal, and formal in nature. When it is informal, it is organized on individual, family or community level. Learning situation is real and natural; 
it takes place at home and in actual places of work i.e. farm, market, workshop, and others; those who serve as teachers are not professionally trained; teacher-pupil/student relationship is direct and personal; teaching is done individually or in small groups while there are opportunities for pupils/students participation; method of teaching is practical and involves teacher demonstrating the skill he/she wishes to teach, among others (Federal Ministry of Education, 1976). Non-formal education consists of functional literacy, remedial, vocational, aesthetic, cultural, civic and continuing education outside the formal school system. It is out-of- school education with no defined age group, rules and regulations, syllabus, certified public examination, and regular certificate (Aghenta, 1999). Formal education is acquired in educational institutions, which can be at primary, secondary or tertiary levels. In Nigeria, primary education is meant for children of the age of between six and eleven (6-11) years. Secondary education is a continuation of primary education and it is meant for a child of the age of 12 years and also divided into three years of Junior Secondary (JS) and three years of Senior Secondary (SS) education. Tertiary education is the last stage of formal education process and aims at enriching the knowledge and skills of a child beyond the level attained at the secondary level so as to ensure his/her successful living in the society. Such education can be acquired in universities, polytechnics, monotechnics, colleges of education, schools of nursing, schools of health technology, schools of midwifery, and others of higher status than the secondary (Federal Republic of Nigeria, 2004, p.36).

In Nigeria, education is expected to:

- Inculcate national consciousness and national unity.

- Inculcate the right type of values and attitudes for the survival of individual and the Nigerian society.

- $\quad$ Train the mind in the understanding the world around.

- Enable a child to acquire appropriate skills, abilities, and competencies, both mental and physical, as equipment to live and contribute to the development of the society (Federal Republic of Nigeria, 2004, p.4).

\section{Teacher in Nigeria's Context}

A teacher is defined in Wikipedia (2009) as a person that facilitates pupil/student's learning in school. Offorma (2009) considers a teacher to be a person who has acquired special skills required for effective imparting of knowledge and skills to a group of learners. In Nigeria, a teacher can be described further as primary teacher (if he/she teaches in primary school); secondary school teacher (if he/she teaches in secondary school) or tertiary institution's teacher (if he/she teaches in any of the tertiary institutions). Teacher can also be described as trained or untrained. A trained teacher is he/she who has passed through educational institutions and in the process acquired the necessary knowledge and skills in teaching. For a teacher to be regarded as trained in Nigeria, he/she might have passed through any of the following institutions and obtain certificate as evidence of attendance: 
- $\quad$ Faculties of Education of Universities

- Colleges of Education

- National Teachers Institute

- Institute of Education of Universities

- School of Education of Polytechnics (Federal Republic of Nigeria, 2004)

They are the teachers with the following qualifications:

- Bachelor of Education (B.ED) degree

- Bachelor of Arts (B.A) degree

- Bachelor of Science-Education (B.Ed. Sc)

- Bachelor of Arts-Education (B.A. Ed)

- $\quad$ Nigerian Certificate in Education (NCE)

- $\quad$ Grade III

- $\quad$ Grade II

There are also teachers who are regarded as untrained. They are those who are yet to receive training in the field of education, particularly in the act of teaching. They are regarded as 'misfits' in the educational system having been employed to teach because of inadequacy of qualified teachers in schools/educational institutions. They are those with the qualifications such as:

- Bachelor of Science (B. Sc) degree

- Bachelor of Arts (B.A) degree

- Bachelor of Technology (B. Tech) degree

- Higher National Diploma (HND) certificate

- Ordinary National Diploma (OND certificate

- Senior School Certificate (SSCE)

For this category of teachers to become trained teachers, they need to enroll for Post-Graduate Diploma in Education (PGDE) programmes (i.e. in the case of those with degree and Higher National Diploma) while in the case of those with Ordinary National Diploma (OND), they have to enroll for either Bachelor of Education, Bachelor of Science/Bachelor of Arts Education or NCE programmes in any of the universities and colleges of education respectively.

\section{Teacher-Related Crises in Nigeria's Educational System}

The role of teachers in educational process cannot be overemphasised. Eduese (1996) admitted that they are the fulcrum on which the lever of educational system rests. In the National Policy of Education (FRN. 2004, p.4), it is stated therein that no nation can rise beyond the quality of teachers in its educational system. Aspects of the crises that relate to teachers include: 


\subsection{Inadequacy and Low Quality of Teachers}

In spite of the role of teacher in the educational system, inadequacy of teachers has been an issue of concern in Nigeria. Many schools in Nigeria lack adequate teachers which have been pronounced in the core subjects such as English Language, Mathematics, Biology, Chemistry, Physics, and other science subjects (Federal Ministry of Education, 2007; Federal Republic of Nigeria, 2009a; Federal Republic of Nigeria, 2009b; Central Bank of Nigeria: 2010). The situation is so grave to the extent that some schools depend on part-time and Parents Teachers Association's (PTA) teachers to teach pupils/students. Associated with this issue of inadequacy is the prevalence of low quality teachers in the educational system. Ordinarily, National Policy on Education (Federal Republic of Nigeria, 2004) stipulates that the minimum qualification for teaching in Nigeria is the Nigerian Certificate in Education (NCE). In spite of the fact that adequate time had been allowed for teachers to upgrade their qualifications to meet the this minimum standard, many teachers still parade Grade III, II, and other lower qualifications in Nigeria (Federal Republic of Nigeria, 2009b: Central Bank of Nigeria, 2010). There are also some teachers who are graduates in their chosen fields but lack the basic teaching qualification thus making them unfit for teaching of pupils/students. Such teachers have only shown interest in teaching due to inability to get job in their chosen fields while they have been recruited due to acute shortage of teachers in the system. At the nursery and kindergarten schools, Ige (2011) reported the prevalence of teachers with Senior School Certificate (SSC) due to the unwillingness of private schools' proprietors to recruit qualified teachers and their wish to maximize profits. Data in Table 1 and 2 show detailed teachers' statistics in primary and post-primary schools in Nigeria.

Table 1: Primary Schools Statistics in Nigeria: 2004-2008

\begin{tabular}{|c|c|c|c|c|c|}
\hline & & & & & Number \\
\hline & 2004 & 2005 & 2006 & $2007 * *$ & 2008* \\
\hline Total Schools & 60,189 & 60,189 & 54,434 & 54,434 & 54,434 \\
\hline Total Enrolment & $21,395,510$ & $22,115,432$ & $23,017,124$ & $21,632,070$ & $21,294,518$ \\
\hline \multicolumn{6}{|l|}{ Total Male } \\
\hline Enrolment & $11,824,494$ & $12,189,073$ & $12,575,689$ & $11,683,503$ & $11,483,943$ \\
\hline \multicolumn{6}{|l|}{ Total Female } \\
\hline Enrolment & $9,571,016$ & $9,926,359$ & $10,441,435$ & $9,948,567$ & $9,810,575$ \\
\hline Total Teachers & 591,474 & 599,172 & 586,749 & 468,202 & 586,930 \\
\hline \multicolumn{6}{|l|}{ Total Male } \\
\hline Teachers & 291,384 & 294,434 & 323,798 & 241,826 & 300,931 \\
\hline \multicolumn{6}{|l|}{ Total Female } \\
\hline Teachers & 300,090 & 304,738 & 262,951 & 226,376 & 285,999 \\
\hline \multicolumn{6}{|l|}{ Total Class } \\
\hline Rooms & 254,319 & 254,319 & 319,590 & 319,590 & 319,590 \\
\hline \multicolumn{6}{|l|}{ Teacher/Pupil } \\
\hline Ratio & 36 & 37 & 39 & 46 & 36 \\
\hline
\end{tabular}

Sources: Federal Ministry of Education/Universal Basic Education Commission (UBEC)

Note: $\quad *=$ Provisional $\quad * *=$ Revised 
Table 2: Post-Primary Schools Statistics in Nigeria: 2004-2008

\begin{tabular}{lrrrrr} 
& & & & & Number \\
\hline & $\mathbf{2 0 0 4}$ & $\mathbf{2 0 0 5}$ & $\mathbf{2 0 0 6}$ & $\mathbf{2 0 0 7}$ & $\mathbf{2 0 0 8 *}$ \\
\hline Total Schools & 10,913 & 10,913 & 18,238 & 18,238 & 18,238 \\
Total Enrolment & $6,279,462$ & $6,398,343$ & $6,536,038$ & $6,068,160$ & $6,625,943$ \\
Total Male Enrolment & $3,539,708$ & $3,543,625$ & $3,642,871$ & $3,460,146$ & $3,682,141$ \\
Total Female & & & & & \\
Enrolment & $2,739,754$ & $2,854,718$ & $2,893,167$ & $2,608,014$ & $2,943,802$ \\
Total Number of & & & & & \\
Teachers & 154,594 & 144,413 & 199,163 & 207,283 & 270,650 \\
Total Male Teachers & 99,403 & 102,469 & 122,462 & 136,285 & 167,527 \\
Total Female Teachers & 55,191 & 56,814 & 76,701 & 70,998 & 103,123 \\
Total Class Rooms & 98,077 & 98,077 & 98,077 & 98,077 & 98,077 \\
Teacher/Student Ratio & 40 & 44 & 32 & 29 & 24 \\
\hline
\end{tabular}

Sources: $\quad$ Federal Ministry of Education

Note: $\quad *=$ Provisional

As indicated in the Table 1, the pupil-teacher ratios exceeded the standard 1: 35 throughout the period which is an indication that there were more pupils relative to teachers at the primary level. It however needs not be overemphasized that the prevalence of inadequate and low quality teachers in schools, calls into question the quality of training that would be provided for pupils/students in schools. Since an individual can only give out what he/she has, such unqualified teachers might not be capable to teach effectively which will undermine the provision of quality education for pupils/students.

\subsection{Poor Commitment of Teachers}

The commitment of teachers in Nigeria leaves much to be desired. Nigeria is a country where teaching is for every Tom, Dick and Harry. Those who cannot find a place in their professions are now involved in teaching. In an ideal situation, teachers are supposed to be dedicated to duty, to justify the confidence reposed in them and the salary they earn from government. What can be noticed in Nigeria is lack of commitment of teachers to teaching (Famade, 2001, Achimugu, 2005). Worried by the situation, Obanya (2004) remarked that many teachers in Nigeria are 'cheaters' which cannot be divorced from the fact that they collect salary which they don't work for. It is unfortunate that in Nigeria, many teachers have turned their full time appointment to part time job, because of the desire to garner additional income to complement their monthly incomes and make ends meet. These days, rather than being in classes, many teachers are commercial drivers and traders in open markets even during school period. Famade (2001) lamented that staff common room are now mini-shops where all sorts of jewelries, shoes and clothes are sold by teachers. To worsen situation, many teachers make use of students/pupils, particularly the female to sell items in schools thus impeding their learning in schools. Some teachers are perpetual absenteeists and late comers in schools. At the tertiary level, many staff had turned their appointments to part time instead 
of the legal full time Some often fail to show up for teaching until few weeks to examination. Those that find it difficult to complete syllabus prefer to compensate students through leakage of questions in handouts and textbooks, in form of 'revision questions', 'areas of focus or concentration' (Ige \& Olowolabi, 2010; Nwadiani, 1999). This has been making many students to pass with good grades without commensurate knowledge in the respective courses.

\subsection{Poor Performances of Pupils and Students in Examinations}

The crisis of poor academic performance of pupils and students has been prevalent in Nigeria's educational system. Over the years, the results of candidates in Senior Secondary Certificate Examinations have been disappointing. Data in Table 3 and 4 shows the performance of Candidates in selected subjects in both the WAEC and NECO administered Senior Secondary Certificate Examination during the period 2004 to 2008.

Table 3: Students' Performance in Selected Subjects in WAEC Senior School Certificate Examinations (SSCE): 2004-2008

\begin{tabular}{|c|c|c|c|c|c|}
\hline Year & 2004 & 2005 & 2006 & 2007 & 2008 \\
\hline \multicolumn{6}{|l|}{ English } \\
\hline Language & & & & & \\
\hline $\begin{array}{l}\text { Total Sat } \\
\text { Total }\end{array}$ & $1,020,431$ & $1,064,587$ & $1,154,266$ & $1,252,570$ & $1,348,214$ \\
\hline $\begin{array}{l}\text { Passed } \\
\text { Total }\end{array}$ & 604,371 & 644,017 & 769,001 & 846,209 & 899,091 \\
\hline $\begin{array}{l}\text { Failed } \\
\text { Mathematics }\end{array}$ & 383,882 & 393,201 & 342,311 & 379,006 & 422,686 \\
\hline $\begin{array}{l}\text { Total Sat } \\
\text { Total }\end{array}$ & $1,019,524$ & $1,054,853$ & $1,149,277$ & $1,249,028$ & $1,340,907$ \\
\hline $\begin{array}{l}\text { Passed } \\
\text { Total }\end{array}$ & 633,594 & 670,582 & 829,999 & 917,868 & $1,086,031$ \\
\hline $\begin{array}{l}\text { Failed } \\
\text { Biology }\end{array}$ & 351,512 & 363,055 & 286,823 & 302,774 & 229,021 \\
\hline $\begin{array}{l}\text { Total Sat } \\
\text { Total }\end{array}$ & $1,005,894$ & $1,051,557$ & $1,137,181$ & $1,238,163$ & $1,332,737$ \\
\hline $\begin{array}{l}\text { Passed } \\
\text { Total }\end{array}$ & 624,647 & 689,677 & 852,171 & 810,564 & 798,341 \\
\hline $\begin{array}{l}\text { Failed } \\
\text { Physics }\end{array}$ & 348,890 & 338,491 & 261,200 & 402,148 & 506,089 \\
\hline $\begin{array}{l}\text { Total Sat } \\
\text { Total }\end{array}$ & 321,499 & 344,411 & 375,824 & 418,593 & 453,173 \\
\hline $\begin{array}{l}\text { Passed } \\
\text { Total }\end{array}$ & 248,849 & 244,979 & 305,224 & 320,969 & 311,823 \\
\hline Failed & 61,940 & 89,150 & 62,119 & 88,480 & 124,420 \\
\hline
\end{tabular}




\section{Economics}

Total Sat

Total

Passed

Total

Failed

Chemistry

Total Sat

Total

Passed

Total

Failed
$973,611 \quad 1,007,710$

1,089,355

$1,183,154$

$1,273,178$

$726,802 \quad 781,286$

896,216

$883,647 \quad 1,038,984$

216,736

206,654

171,145

270,918

212,481 Nigeria (2009). Abstract of Statistics.

Table 4: Students' Performance in Selected Subjects in NECO Senior School Certificate Examinations (SSCE): 2004-2008

\begin{tabular}{lrrrrr}
\hline \multicolumn{1}{c}{ Year } & $\mathbf{2 0 0 4}$ & $\mathbf{2 0 0 5}$ & $\mathbf{2 0 0 6}$ & $\mathbf{2 0 0 7}$ & $\mathbf{2 0 0 8}$ \\
\hline English Language & & & & & \\
Total Sat & 878,125 & 840,024 & 901,135 & 989,765 & $1,108,826$ \\
Total Passed & 537,466 & 497,666 & 620,831 & 812,613 & 952,306 \\
Total Failed & 287,070 & 281,631 & 222,369 & 137,141 & 96,248 \\
Mathematics & & & & & \\
Total Sat & 873,989 & 838,012 & 897,791 & 961,455 & $1,092,215$ \\
Total Passed & 508,425 & 557,079 & 634,605 & 699,966 & 939,460 \\
Total Failed & 302,242 & 215,058 & 188,360 & 201,753 & 90,204 \\
Biology & & & & & \\
Total Sat & 863,771 & 835,012 & 890,866 & 980,337 & $1,082,262$ \\
Total Passed & 601,112 & 552,454 & 652,493 & 743,297 & 929,820 \\
Total Failed & 223,152 & 228,383 & 178,245 & 195,189 & 94,518 \\
Physics & & & & & \\
Total Sat & 271,539 & 266,913 & 288,051 & 327,669 & 360,102 \\
Total Passed & 243,958 & 207,038 & 216,682 & 258,067 & 317,112 \\
Total Failed & 16,305 & 45,458 & 56,505 & 57,539 & 24,095 \\
Economics & & & & & \\
Total Sat & 815,420 & 782,448 & 833,862 & 908,285 & $1,006,523$ \\
Total Passed & 594,892 & 535,963 & 659,830 & 721,926 & 877,197 \\
Total Failed & 187,182 & 190,967 & 113,576 & 151,458 & 72,576 \\
Chemistry & & & & & \\
Total Sat & 277,383 & 270,828 & 291,344 & 333,303 & 344,766 \\
Total Passed & 194,622 & 46,422 & 206,874 & 259,755 & 302,553 \\
Total Failed & 68,810 & 81,969 & 67,739 & 61,019 & 25,595 \\
Geography & & & & &
\end{tabular}


Total Sat

Total Passed

Total Failed

\section{Government}

Total Sat

Total Passed

Total Failed

Agricultural Science

Total Sat

Total Passed

Total Failed

\section{Further Mathematics}

Total Sat

Total Passed

Total Failed

Commerce

Total Sat

Total Passed

Total Failed

\section{Electronics}

Total Sat

Total Passed

Total Failed

\begin{abstract}
506,175
\end{abstract}
378a,735

114,469

525,012

390,034

122,294

522,140

374,453

121,226

703,279

496,495

714,541

588,569

185,834

92,844

688,173

485,112

158,869

14,225

10,737

16,497

15,710

15,277

12,598

319

1,306

348,938

276,004

351,094

316,280

284,470

236,379

66,189

56,077

732,054

565,031

119,837

807,878

645,309

128,975

621,922

497,084

100,241

583,681

474,365

89,489

Source: National Examinations Council (NECO), in Federal Republic of Nigeria

(2009). Annual Abstract of Statistics

It can be noticed in Table 3 and 4 that there were mass failure of students in Senior Secondary Certificate Examination (SSCE) in Nigeria during the period. A factor which can be traced to the poor academic performance of pupils/students is ineffectiveness of teachers (Nwagbo, 2007; Yusuf, 2008). When a teacher is not committed to teaching, the subjects' syllabuses would not be covered while pupils/students would not be appropriately taught. There is thus the tendency for such pupils/students to fail examinations at the end of the term, session or career. It is worthy of note that the low commitment and ineffectiveness of teachers which is reflecting in poor academic performances as well as involvement in examinations malpractice has led to the crisis of degrading quality of education, particularly the quality of pupils/students that graduate from schools these days (Ige, 2011).

\subsection{Issue of Wastage}

In Nigeria, many teachers take delight in indulging in immoral relationship with female pupils/students (Ajayi \& Shofoyeke, 2003; Achimugu, 2005). Some are fond of collecting money from pupils/students in exchange for marks while some go to the extent of punishing female pupils/students that refuse to cooperate thus encouraging the crisis of dropout in the system. In what seems to be a paradox, while Nigeria is striving towards achieving Education for All goals, in 2015, many pupils are out of school and dropping out from schools (Nigeria 
Education Sector Diagnosis, 2005; Abonyi., Nwoba \& Attamah, 2011). Data in Table 5 show the net enrolment and completion rates in primary education in Nigeria between 1991 and 2008.

Table 5: Net Enrolment \& Completion rate in Primary Education in Nigeria

\begin{tabular}{lcccccl}
\hline & \multicolumn{3}{c}{ Enrolment (\%) } & \multicolumn{3}{c}{ Completion (\%) } \\
\hline & 1991 & 2008 & $\begin{array}{l}\text { Change } \\
\text { (\%) }\end{array}$ & 1991 & 2008 & Change \\
Male & 64.6 & 63.5 & -1.70 & 93.3 & 81.8 & -12.33 \\
Female & 50.8 & 56.5 & 11.22 & 77.5 & 68.2 & -12.00 \\
\hline
\end{tabular}

Source: United Nations Statistics, cited in Abonyi, O.S; Nwoba, P.A and Attamah, G.G. (2011).

Reforms in Science, Technology, Engineering Education (STEM): Evaluation of the AU/NEPAD African Action Plan.

As indicated in Table 5, male enrolment rate was 64.6\% in 1991 but decreased to $63.5 \%$ in 2008. Female enrolment was $50.8 \%$ but increased to $56.5 \%$ in 2008 . Male completion rate was $93.3 \%$ in 1991 but decreased to $81.8 \%$ in 2008 . The female completion rate was $77.55 \%$ in 1991 while it was $68.2 \%$ in 2008. It is worthy of note that many among the cases of wastage in school in Nigeria can be traced to teachers attitudes in schools such as pregnancy of female children, victimization of female students/pupils as a result of refusal of love relationship by female students among others.

\subsection{Examination Malpractices}

It is not a gainsaying that examination malpractice has becomes 'a demon with more than a thousand faces' in Nigeria. Awe (2004) reported that in year 2000, West African Examinations Council (WAEC) cancelled 41,030 results including 14, 073 in Mathematics, 8,705 in English and 6,681 in Biology. In 2001, 51,383 results were cancelled indicating 25\% increase over that of year 2000. In 2002, 137,326 results were sanctioned due to different kinds of malpractices. As at 2003, the Examination Ethics Project reported that out of 929,294 candidates that sat for the May/June WAEC O' level examination, 111,969 representing (12.05\%) were caught cheating. In 2004, the Examination Malpractice Index (EMI) in Nigeria increased to $16.9 \%$ thus indicating that for every 100 candidates that sat for the examination, 16-17 among them were caught cheating. Reports by West African Examinations Council (WAEC), as cited in Daily Sun Newspaper of $29^{\text {th }}$ August, 2006, also indicates that between May/June 1995 and May/June 2006, 14,408,336 candidates sat for SSCE while 1,367,726 among them, representing 9.4\%, were involved in examination malpractices. Nanna (1997); Azuka, Alutu and Aluede (2006); Awe (2004); Adelusi (1998) however linked teachers with cases of examination malpractices in Nigeria. According to Adelusi (1998), the poor condition of service of teachers coupled with the unstable economic situation in Nigeria, has made teachers to renounce the saying that 'their reward is in heaven'. Many teachers thus want their reward on earth which is why they indulge in different kinds of unwholesome practices in an attempt to make money at all cost. The involvement of teachers 
in examination malpractices is a matter of concern, embarrassment and disappointment to the education stakeholders because in an ideal situation, teachers who are at the centre stage of the teaching-learning process in schools, are supposed to display good moral etiquette and be role models to pupils/students.

\subsection{Indiscipline of Pupils and Students}

What can be noticed in Nigeria is the increasing rate of indiscipline of pupils and students in schools. At the primary and secondary levels, cases of alcohol consumption, rape, wearing of unauthorized and assorted dresses, smoking of Indian hemp and cigarettes, staying in hostel during lesson, stealing, truancy, are few among the negative attitudes of pupils/students (Nwana, 1998). At the tertiary level, student unrest and cultism are also prevalent (Saint, Hartnett and Strassner, 2003; Akpabio, 2001). Among the factors behind the cases of indiscipline are school based factors such as: inadequate teachers; professional incompetence of teachers; undue familiarity of teachers and students; moral laxity of teachers which prevents them from becoming role models to pupils/students; lack of motivation or encouragement to teachers; frequent transfer of teachers and discrimination by school principal just to mention few (Afolabi, 1998; Yaroson, 2004).

\section{Teacher-Related Crises in Educational System: The Way Forward in Nigeria}

In view of the role of teacher in educational system and the dearth of teachers in schools in Nigeria, additional teachers should be recruited and posted to schools. Efforts should be made to improve the quality of teachers in schools which can be achieved if the deadline for upgrading the qualification of teachers to the minimum standard (i.e. NCE) is extended by another five years. There should be in-service training of teachers to improve their competency. Sponsoring them to seminars, workshops, and conferences can help to achieve improved quality of teachers in schools.

In as much as lack of motivation has been identified as one of the factors that can enhance teachers' effectiveness in schools (Ogunsaju, 2004; Ayeni, 2005). In view of this, Government should give priority to teachers' welfare, to avoid unnecessary strikes in schools. Of recent, Federal Government approved a special package (i.e. 27.5\% salary increase) for teachers in Nigeria. Unfortunately, many States in the country are yet to implement this package which has been causing strikes in the States and interruption in the academic calendar of schools. Government at the states' level, thus need to pay this package to encourage teachers towards improved performance and improve their status in the society. Teachers in difficult and rural areas can also be motivated through the payment of additional allowance by Government.

Government should enforce the law against examination malpractice in Nigeria. Those caught in the act should be punished to serve as deterrent to others. Teachers, being role models to pupils/students, should refrain from examination malpractices. Parents owe it a duty to provide good moral training for their children so that they can refrain from examination malpractice and other negative behaviours in schools. Educational institutions' administrators should ensure that there is high-level discipline in their schools. At the tertiary level, issues of 
student unrest and cultism should be eradicated. There is need for orientation of new teachers in schools so as to expose them to the realities in the schools' environment. There should also be regular monitoring of teachers to ensure that there is no deviation from the standard. Ministry of Education and other Government's agency in charge of inspection should be alive to their responsibilities and be fortified through improved funding, to ensure regular and prompt inspection of schools.

Educational institutions' administrators should be alive to their responsibilities. They should supervise teachers and ensure that they discharge their duties conscientiously. Teachers that show dereliction of duties should be punished. After the recruitment and posting of teachers to school, they should be attached to experienced and qualified teachers so as to gather more experience for improved performance. Government should pay teachers' salaries and allowances promptly, promote them as at when due, so as to encourage them towards effective performance of their duties in schools. Teaching should be professionalized in Nigeria. Although Teachers Registration Council of Nigeria (TRCN) is making frantic efforts towards achieving this feat, there is need for quick actualization of it by government because it will separate the 'wheat from the chaff' and enhance the status of teaching in Nigeria.

\section{Summary and Conclusion}

It is not a gainsaying that teachers are indispensable in the educational system. In view of their roles, attention need be paid to issues concerning them so that there would not be problem in the educational system. This paper examined the aspects of educational crises in Nigeria which centre round teachers while suggestions that can help in combating these crises were also raised. Government, Parents, school's administrators however need to adopt these strategies, to achieve this feat. It is hopeful that if teachers' related crises are solved, the state of education would improve in Nigeria.

\section{References}

Abonye, O.S., Nwoba, P.A., \& Attamah, C.G. (2011, $15^{\text {th }}-22^{\text {nd }}$ August). Reforms in Science, Technology, Engineering \& Mathematics Education (STEM): Evaluation of the AU/NEPAD African Action plan. Paper presented at the $52^{\text {nd }}$ Science Teachers Association of Nigeria (STAN) Conference, held at Akure, Nigeria.

Achimugu, L. (2005). The agonies of Nigerian teachers. Port Harcourt, Nigeria: Baren Press Limited.

Adelusi R.A. (1998, $10^{\text {th }}-12^{\text {th }}$ February). Moral, Social and Legal Approaches to Solving the Problem of Examination Malpractices in Nigeria. Paper delivered at the workshop on Examination Malpractice, organized by Ondo State Ministry of Education, Akure, Nigeria.

Adesina, S. (1977). Planning and educational development in Nigeria. Lagos: Educational Industries Limited. 
Afolabi, F.O. (1998). Basic concepts in school administration and supervision. Ondo, Nigeria: Patrick Ade Press.

Aghenta, J.A. (1999, $6^{\text {th }}$ August).Human Resource Development in Nigeria: The Process,

Ajayi, T., \& Shofoyeke, A. (2003). School Discipline, Teachers Attitude and Ethics of the Teaching Profession. Paper presented at the workshop on skills improvement programme for performance of teachers in Ondo State, Nigeria.

Akpabio, E. (2001, $3^{\text {rd }}-7^{\text {th }}$ July).Public Relations and Crisis Management Strategy for Student Protests in Nigerian Universities. Paper presented at the $12^{\text {th }}$ General Assembly of Social Science Academy of Nigeria.

Awe, R. (2004, 17 ${ }^{\text {th }}-25^{\text {th }}$ February). Curbing Examination Malpractices in Post-Primary Schools in Ondo State. Paper presented at a Workshop for Principals, Teachers and Students by Ondo State Ministry of Education, Nigeria.

Ayeni, A. J. (2005). The effect of principals' leadership styles on motivation of teachers for job performance in secondary schools in Akure South Local Government. An Unpublished M.A Ed Thesis submitted to the Department of Educational Administration and Planning. Obafemi Awolowo University, Ile-Ife.

Azuka N.G., Alutu., \& Aluede, O. (2006). Secondary schools student's perception of examination malpractices and examination ethics. Journal of Human Ecology, 20(4): 295-300.

Callaway, A.C. (1967). Dropouts from Nigeria’s schools. Ibadan, Nigeria: Nigerian Institute of Social and Economic Research (NISER) Monograph Series.

Central Bank of Nigeria (2010). Statistical Bulletin. Abuja, Nigeria: Federal Government Press.

Chukwuemeka, P.C. (2011, $15^{\text {th }}-23^{\text {rd }}$ August). Competency based Biology Teacher Education Programme: Implications for Science education sector reforms in Nigeria. Paper presented at the $52^{\text {nd }}$ Science Teachers Association of Nigeria (STAN) Conference, held at Akure, Nigeria.

Daily Sun (2006, 29 $9^{\text {th }}$ August, p.18). Stakeholders brainstorm on examination malpractice.

Eduese, E.D. (1996). Teachers: The issue of quality, quantity and cost in Nigerian secondary Schools. Journal of All Nigerian Conference of Principals of Secondary Schools, 4(2).

Fafunwa, A.B. (1974). History of education in Nigeria. U.K; George Allen \& Urwin Limited.

Famade A.O. (2001). Sociological foundations of education. Lagos, Nigeria: Pumack Nigeria Limited.

Federal Ministry of Education (1976). Foundations of educational thought and practice. Lagos, Nigeria: Nigeria Educational Research Council.

Federal Ministry of Education (2005). Nigeria Education Sector Diagnosis. Abuja, Nigeria: 
Federal Government Press.

Federal Ministry of Education (2007). Statistics of education in Nigeria: 1999-2005. Abuja, Nigeria: Federal Government Press.

Federal Republic of Nigeria (2004). National Policy on Education (Revised). Abuja, Nigeria: Federal Government's Press.

Federal Republic of Nigeria (2009a). Statistics of education in Nigeria. Abuja, Nigeria: Federal Inspectorate Service.

Federal Republic of Nigeria (2009b). Annual abstract of statistics. Abuja, Nigeria: Federal Government Press.

Federal Republic of Nigeria (2009b). The state of education in Nigeria. Abuja, Nigeria: Federal Government Press.

Ibeh, I. (2009, 27 ${ }^{\text {th }}$ August). Why many unemployed graduates in Nigeria? Daily Triumph.

Ibukun, W.O. (2009, $5^{\text {th }}$ October). Build the Future: Invest in Teachers now. Paper presented at the World Teachers Day, held at Akure, Nigeria.

Ige, A.M. (2011). Challenges facing Early Childhood Care, Development and Education in an era of Universal Basic Education in Nigeria. Early Childhood Education Journal, 39(2), 161-167. http://dx.doi.org/10.1007/s10643-011-0443-3

Ige, A.M. (2012). Myths and Reality of Falling Standard of Education in Nigeria: The Way Forward. Nigerian Journal of Professional Teachers, 2, 36-48.

Ige, A.M., \& Olowolabi, S. (2010).Student Unrest in Tertiary Institutions in Nigeria: Causes and Remedies. Journal of Educational Research and Development, 4(3), 137-146.

Nanna, E. M. (1997). Teacher's Behaviour amongst School Pupils as a factor in Examination Malpractice in Secondary School: A Study of Schools in Ughelli North Local Government Area of Delta State. Unpublished Bachelor of Education Project, Edo State University, Ekpoma, Nigeria.

Nwadiani, M. (1999). Dystrophies in higher education: Nigerian experience. Higher Education Review, 31(3), 17-26.

Nwagbo, C.R. (2007, April). Developing observational and drawing skills in teachers foreffective conduct of biology practicals. Paper presented at the Biology Workshop of Science Teachers Association of Nigeria (STAN), held at Jos, Nigeria.

Nwana, O.C (1998). Aberration in Nigerian education system. UNESCO (Ed). The state of education in Nigeria. Abuja, Nigeria: UNESCO Regional Office.

Obanya, P. (2004). The dilemma of education in Africa. Ibadan, Nigeria: Heinemann educational books Plc. 


\section{Macrothink}

International Journal of Education ISSN 1948-5476 2012, Vol. 4, No. 4

Offorma, G.C. (2009, $16^{\text {th }}-19^{\text {th }}$ July). Girl-Child Education in Africa. Keynote address at the Conference of the Federation of the University Women of Africa, held in Lagos, Nigeria.

Ogunsaju, S. (2004). A guide to school effectiveness in Nigeria. Ibadan. Laville Publications.

Problems and Prospects. Lecture delivered to students of College of Education, Agbor, Delta State, Nigeria.

Saint, W., Hartnett, T.A., \& Strassner, E (2003). Higher education in Nigeria: A status report. Higher Education Policy, 16, 259-281. http://dx.doi.org/10.1057/palgrave.hep.8300021

Ukeje, B.O. (1991). Financing education in Nigeria: Future Prospects, in R.O Ohuche (Ed).Moving Education in Nigeria toward the Year 2000.Proceeedings of the $1^{\text {st }}, 2^{\text {nd }}$ \& $3^{\text {rd }}$ Congresses of Nigeria Academy of Education. Enugu, Nigeria: Optimal Solutions \& Nigeria Academy of Education.

Universal Basic Education Programme (2002). Routine monitoring report. Department of Monitoring and Evaluation, Universal Basic Education Commission, Abuja, Nigeria.

Wikipedia (2009). The free Encyclopedia.

Yaroson, M.C. (2004, $9^{\text {th }}-11^{\text {th }}$ August). Strategies for Curbing Indiscipline in Nigerian Secondary Schools. Paper presented at the National workshop on developing education: Issues of standard and sustainability in secondary schools in Nigeria.

Yusuf, A.A. (2008). Basic laboratory techniques and procedures for laboratory assistants and attendants. A training manual by Nigeria Institute of Science Laboratory Technology.

\section{Copyright Disclaimer}

Copyright reserved by the author(s).

This article is an open-access article distributed under the terms and conditions of the Creative Commons Attribution license (http://creativecommons.org/licenses/by/3.0/). 